\title{
Economic and Accounting Interpretative Approach on Income Disparity: Evidence from China
}

\author{
Dr Edward Wong Sek Khin \\ University of Malaya \\ 50603, Kuala Lumpur, Malaysia \\ E-mail: edwardwong@graduate.uwa.edu.au
}

\begin{abstract}
In this paper, we analyse the current China urban and rural income disparity. Our analysis demonstrates that the Economic and Policy reforms instituted by the Chinese government over the past decade or so have had two primary aims: Firstly, to maintain political stability at all costs and secondly to transform China into a modern industrial state. To ensure political stability, it has eschewed the current Russian model for a unique Chinese model where state owned enterprises co-exist with market driven businesses. This all began in 1978, after two disastrous near revolutions where the hard-line Marxist-Socialists had to concede that all was not well for the future of China, in a modern world. Beginning with the rural sector, where the pool of greatest poverty existed and improving in that sector firstly, allowed the market-oriented to greatly improve their incomes, thus changing the disparities between urban and rural economics. The period of 1985 to 2005 was a period of almost exponential growth, and the raising of millions out of poverty was only part of the positive results, but the greatest social negative was that inequality became worse, as is found in most Capitalist societies. There seems to be an initial jump in the incomes of rural China to jump out of poverty, but the effects have slowed, and it is now up to government agencies to aid the remaining impoverished to escape the traps of poverty through education and relocation incentives for industry, domestic and foreign. This does not mean throwing money at the problem, it means preventing destitution, as destitution adds to crime and other anti-social events and greatly increases instability, the anti-thesis of current Chinese policy.

Perhaps the question ought to be a rethink of agricultural policies, to generate corporate farming, as opposed to collective farming, all in order to reduce rural poverty and make rural businesses into a proper and profitable sector of employment
\end{abstract}

Keywords: Poverty, Income disparity, Capitalism, Chinese policy, Urban and rural economic reforms

\section{Introduction}

Since 1978 China has reformed itself into the half-socialist half-capitalist economy of today, as well as generating a fundamental economic shift from a rural agrarian economy to a fully functioning industrial economy based upon its vast and cheap labour supply, and all of this under the tutelage of Deng Xiao Ping, head of state and head of the Communist Party of the People's Republic of China. The results have been spectacular as the real Gross Domestic Product (GDP) increased an average of 9 percent per annum and the per capita income grew some fourfold. This effectively reduced that part of the population living below the local equivalent of a poverty line by almost two-thirds, from 200 million to about 70 million during the period from 1978 to 1996. This improvement has also raised the level of bank savings by more than 70 times, from 21 billion in 1978 to 1,520 billion Yuan in 1993 and 11,955 billion Yuan in 2004.

Although the People's Republic of China (PRC) has an established Marxist-Socialist Constitution, these last few years have led to wide differences in available and disposable incomes within the population of that country, and within various regions of the country as well, in effect it has become the very antithesis of a Socialist-Communist country. Other situations not common under the previous regime have now arisen - unemployment, individual risk taking yielding great rewards, individualism expressed not only in business but in other areas, but not in areas of fundamental political activity. Also the cross subsidisation of various regions and industries have now disappeared and the 'shared prosperity' and 'shared poverty' of the past, has been replaced by almost Dickens-like descriptions of the industries of China. 
However, not all is abandoned to the might of Capitalism. Lately, rural wages are beginning to increase; new programs to encourage rural communities and the upgrading of facilities available in these rural areas are now beginning to attract attention and Central Government funding.

For the first time, perhaps, in Chinese history, modern and unfettered capitalism is changing the face of China and the financial divisions within any such society are beginning to show. Shanghai, is the financial centre, Beijing the political centre, with the regional centres relying upon these two major concentrations to determine the social, political, and economic decisions made in a local sense. The reliance on a Central Planning Committee, though the offices of the local Communist Party's connections with Beijing are now past, it is now every decision made for development or administration has shifted to local offices with the broad outlines supplied by the Central Government.

The reality of China is one of turmoil for about the next ten to twenty years, as its vast rural population, under-educated and ignorant of modern political and business methods, is that part of the wider Chinese population that will have to bear the greatest burden of a personal and effective education in modernity. This will mean an initial sharp difference between the incomes of the rural and urban dweller until the rural dweller discovers their real power lay in their supplying of foodstuffs to the cities. The modernisations of rural farms will perhaps, creates a vast pool of under-educated farm labourers who by economic necessity will move to the cities seeking employment. This is exactly what happened to Britain during the beginning of its Industrial Revolution, which may lead to the formation of trade unions in a "worker's paradise." However, the newly formed middle and wealthy classes, have yet to recognise that their incomes, speculative and non-speculative are at risk from a possible seething rural underclass, which by remembering the last political upheaval in the "Cultural Revolution," create another revolution with more egalitarian result for this currently overlarge portion of the population.

\section{Insert Figure 1-1 Here}

\subsection{Analysis of the Current Income Disparity in China}

\subsubsection{General overview}

\section{City and Rural Income Disparity.}

The reforms that began in 1978 have increased the living standards of rural China, but not as fast or as high as urban China. The releasing of rural China from a good deal of the straitjacket of Central Planning, has led to areas of profitable agricultural specialisation as well as traditional cropping. (Note 2) The creation of new enterprises that encompass towns and villages as businesses or even co-operatives, are the major source of income increases in the rural areas. Using Figure 2-1, the income distribution among rural residents has made almost unbelievable progress in the 16 year time scale used. We can see that the incomes of rural China has been almost totally reversed from where almost 90 percent were impoverished to where almost 90 percent have a liveable income. For example, from 1990 to 2005 , we can see a significantly improved balance among different household group, in the category of less than 500 Yuan the ratio dropped from 35.05 in 1995 to 1.68 in 2005 . In the category of more than 3500 Yuan the ratio increased from 0 in 1996 to 37.1 in 2005 (Table 2.1).

\section{Insert Figure 2-1 Here}

\section{Insert Table 2-1 Here}

Fig 2.1 and Table 2.1 were extension of Dr Taejoon Han (1995) paper "China: A share poverty to uneven wealth? (1995).

However, the greatest 'winners' were the urban dwellers. The proportion of rural incomes to urban income in China is 40 percent, while in most other countries the ratio is at least two thirds or better in 1995. (Note 3) However, from 1996 to 2006, the income gap between urban and rural areas has experienced from gradual enlargement to speedy enlargement. The ratio between urban and rural residents reached from 2.27:1 in 1996 to 3.22:1 in 2006. Figure 2-3 shows graphically the improvement of rural and urban incomes but also their disparity as well. This disparity is, in part, due to the effects of government policies that encourage urban incomes to rise, mainly through subsides in investments, housing, pensions, and superior health care through health insurance and better health facilities. (Note 4)

These real differences are contributing to the de-population of rural areas to the cities, which may not necessarily have a labour shortage, which may lead to a situation of urban destitution instead of rural near-poverty. Still, China has an imbalance of population even when it is declining. The rural population has decreased some ten percentage points, from 80 odd percent to 70 odd percent and is till on the decline, over this period. Another problem is the sale of farmland for industrial purposes, reducing the available arable land by roughly half of one percent annually. With a declining population and a reduction of arable farm land, a question arises as to whether or not farm efficiency can be improved sufficiently to enable China to remain self sufficient in its major foodstuff production in the future. Perhaps China is hoping for a similar population proportion of rural workers to urban dwellers as are found in Western Nations, some 3 
to 5 percent. If this is so, one can readily see the shift from rural to urban population has a long way to travel at this time.

\section{Insert Figure 2-2 Here}

Insert Table 2-2 Here

Figure 2.2 and Table 2.2 were extension of Dr Taejoon Han (1995) paper "China: A share poverty to uneven wealth? (1995).

\section{Insert Figure 2-3 Here}

\section{Insert Table 2-3 Here}

Fig 2.3 and Table 2.3 were extension of Dr Taejoon Han (1995) paper "China: A share poverty to uneven wealth? (1995).

\section{Regional Income Disparities}

Regional income differences are shown in table 2.3 above. The differences between the highest income levels both urban and rural incomes are compared with the following ratios. Shanghai has the highest levels of income, both rural and urban. The ratio of Shanghai, which is located in the eastern region to the lowest income levels of Guizhou, which is located in the central region are in the ration of about 2.5 to 1 in Shanghai's favour in urban incomes, but perhaps more importantly almost 4.4 to 1 in rural incomes in Shanghai's favour. This disparity may be more to Shanghai's favour than immediately apparent. If more and more of Shanghai's rural communities move to urban areas, then experienced rural workers and farmers will move into Shanghai's rural areas to replace those that have moved to city factory employment. This change in demographic resources, if not hindered by tribal or community prejudices, will slowly enable even the most primitive rural population to have access to a better life, both from the actual population shift as well as allowing for less labour intensive farming methods without population displacement, the very thing that has caused revolutions elsewhere and at earlier times. For instance in table 2.4, in 2005, per capital GDP and the total GDP of the eastern region were 2.0 times and 6.0 times larger respectively than those of the western region.

\section{Insert Table 2-4 Here}

Table 2.4 was extension of Dr Taejoon Han (1995) paper "China: A share poverty to uneven wealth? (1995).

\subsection{Income Variations within Urban Areas}

The differences in income levels within an urban community are also under consideration. The change from an apparent egalitarian state with privileges according to one's position in a state owned organisation, to a situation where income differences are apparent due to skills, education or property ownership or all of these, is new to the China of the late $20^{\text {th }}$ century onwards. The differences between the lowest paid and the highest paid remains in low multiples when compared with Western organisations. However the resentment is that before all were 'paid' equally, some are now 'more equal than others.' As shown in the following table 2.3, the per capital income of the top 5 region urban income earners in 2005 was 2 times greater than the bottom 5 region urban in 2005. However, the per capital income of the top 5 region rural income earners in 2005 was 8.5 times greater than the bottom 5 region in 2005 . This showed that city dwellers suffered the income inequality among themselves, but not as great as the rural residents.

As there is no unemployment insurance or social security as western countries are familiar, to be unemployed is more than an economic problem; it is a personal economic disaster. Previously under the Socialist-Communist system, it was illegal to be unemployed, and when change occurs as fast as it has in China, there is no corresponding system or modifications to the current system to grasp the increasing numbers of unemployed.

\subsection{Apparent Causes of Income Disparity}

When China recognised, as did the Soviet Union, that Marxist Socialism could not effectively compete with Capitalism, these two countries divested their governments of state ownership when deemed 'more profitable' for the government. In reality, it meant that the factory managers became factory owners, and paid a pittance for assets worth millions to replace. In general, the newly wealthy of both China and Russia suspiciously used apparent graft and corruption in order to secure their assets and incomes. There are gaping holes in taxation laws and property laws as to property rights and real property law. Eventually the law must catch up but until then the monetary costs of the lack of a legally complete property and income laws means that Western 'outlaw practices' reign freely and with little or no hindrance.

\subsection{Exploitation of Government policy}

Included are exploitation of new Government policies, loopholes in the laws as regarding business in general, abuse of power, cronyism, tax evasion and many other factors that lead to general dissatisfaction in any given community, if such practices are exposed by a free press (which China does not yet possess.) The first is peculiarly Chinese. 
Parts of organisational income is deposited as personal savings which bypasses the taxation authorities and gains higher than usual interest rates. The higher interest rates have caused funds to flood into such accounts, amount far greater than just personal savings. (Note 7) The increases could been sourced from the incomes of the Chinese workers, as the increases have been of such a magnitude that the increases have been nearly 4 times the total wage payments made nationwide.

Tax evasion is as prevalent as the most tax evasive European countries, France and Italy, and the lack of proper tax laws and tax law enforcement, some 50 percent of individuals and 90 odd percent of businesses actively evade tax.

\subsection{Regional Income Differentiation}

China in so many ways has yet to become a monolithic economy, has not yet happened in North America, nor in Europe. China Inc. has yet to be developed. Since the creation of the PRC, most of China's industrialisation has occurred on the coastal areas. (Note 8) When the era of Communist and therefore central planning greatly influenced the direction of industrial development, a shift away from coastal area industrialisation was begun, fulfilling new policy directions at that time. (Note 9) The led to a new policy of self reliance for each region that is each region was master of itself as an autonomous unit to enable each region to ignore market forces or a Beijing Central Planning process. However, the lack of solid management and uses of local advantage meant that this policy was not successful. This lack of success caused massive losses of state owned and collective assets later when the reforms were about to take place. During this phase of the modernisation of China, criminal activity - theft, embezzlement, fraud, and other thefts by persons in power, converted inefficient state owned factories into inefficient privately owned assets sometimes on-sold at a great profit.

Table 2-5 indicates these gaps between four regions.

\subsection{Disparity of Available Worker Populations between Coastal and Interior areas}

Most of China's primary mineral and forestry assets are in North-western and Central China and as table 2.5 indicates a minority of China's labour force is available to exploit these areas. The Coastal areas have developed into financial centres and not industrial centres and though this has allowed massive wealth and capital accumulation, there are areas which need capital injections to upgrade and improve and begin new industries, and not just real estate and similar investments.

\section{Insert Table 2-5 Here}

*1: Figures in 10,000 persons

*3: Figures at current prices in 100 million Yuan.

*4: Figures in 10,000 units.

*5: Figures in 100 million kwh.

*6: Number of regular institutes of higher education.

Table 2.5 was extension of Dr Taejoon Han (1995) paper “China: A share poverty to uneven wealth? (1995).

The concentration of wealth from near speculative investments in the coastal areas of China to the exclusion of longer-term investment in technologies and improvements needed in the industrialisation of the resource rich interior has created a short term investment mentality while the competitors of China take a much longer view. This may well create great economic instability in the near future as better education reaches the interior without commensurate employment opportunities for these newly educated Chinese.

\section{Discussions}

So far we have only discussed wage payment and have ignored non-wage components of a salary. These are such things as improved medical insurance, education facilities for both employee and their children through subsidies, housing subsidies of various types, and so on. Rural communities may not be able to match any of these non-wage payments, but then again maybe they do not have to do so, if the living conditions in rural areas are better than urban areas

Being able to see statistical data (table 2.2, 2.3, 2.4, 2.5) that show disparities among cities, among areas and regions, only shows that the data can be determined by the rationale of the data collection and the questions asked. There are great disparities that the data does not show and this is from the assumption that the data collection may be contaminated by the 'political correctness' of the times, or by direct omissions in its collection. Though this is a case of doubting the veracity of the data, it is not unique only to China, whether under a strict Marxist-socialist structure and ideology or in a more tolerant version of that doctrine.

What seems to be the important part of the data is that the disparities are real and by necessity have to be quickly addressed by all levels of government to ensure a future for rural and resource rich communities within the nation and to ensure sovereign control of all resources within the borders of China for the benefit of all of China. Secondly to 
de-centralise decision making to allow decision making to become efficient and local to yield local benefits when successful, and localised pain when they are not.

If the data are incomplete, then only a small picture is drawn from the data, and that new data must be collected to show the importance of the rural and urban communities and the levels of poverty or near poverty generated by the lack of resources being invested into productive endeavours outside the norm.

\section{Insert Table 2-6 Here}

*1: (Total population / Total employed persons) * 100 Source: China Annual Statistics Book, 2005.

*3: Number of telephone sets per person.

*3: Actual numbers should be divided by 10,000 .

*4: Regular institutes of higher education.

Table 2.6 was extension of Dr Taejoon Han (1995) paper "China: A share poverty to uneven wealth? (1995).

Even though there have been many studies of poverty in China, and governments historically have rejected nearly all of these studies, mainly to maintain the theory that with such a vast population, to attain near parity with the Western standard of living would take an investment greater than the wealth available in the entire world. While this may be true at a given time, it does not mean that China could not do this over a period. A tool used by many analysts, the Gini-coefficient is an imperfect measure, but literally the only one used over a spread of many countries and places. Again as with any other form of measurement, what is deemed to be measured may or even cannot measure what it purports to measure, but stands a at least a beginning of a description. Poverty is the measure of the Gini-coefficient, and when it is used in massive population, such as China, and then compared with other less populated places, the Gini-coefficient breaks down as a tool for comparisons. The only comparisons that could be made in this instance is to compare like places with like, such as India with China, and both are poor countries, and the Gini-coefficient only measures income and not wealth such as property or shares in corporations. In addition, the Gini-coefficient is a static measure, but it does have some advantage in it use as it can be plotted over time. This does not mean that any other method is better, as there is no perfect measure of poverty and income and as Choi (1996) concludes the results of other methods yield results that are different in magnitude when dealing with China. (Note 11) Choi seeks a new and dynamic measure to overcome the disadvantages and misleading results that current methods possess.

Using, again, figure 2.1 in the comparison of the wage income of rural workers, there is a increase in this income from the 1990s to 2006, but using the Gini-coefficient, urban dwellers had a higher income increase. Table 2-3, using the Gini-coefficient as the measure, shows that the income disparity of urban dwellers over rural dwellers increased as measured by this coefficient. Part of the reason of this increasing disparity is that due to the socialist-communist government at this time, almost everyone had an income of less than 500 Yuan per month. However, as rural incomes increased, the disparity of rural and urban incomes increased as well (refer to table 2.7).

\section{Insert Table 2-7 Here}

Questions then are asked in the attempt to compare income distributions of various other places with China using the Gini-coefficient, even though it has a measurement problem, as well as a data problem. Is China really a poor country? How unequal is the income distributions among rural and urban residents and among regions in China? Is a comparison with other developing countries valid? Is a comparison with developed countries valid? Table 2-8 shows a Gini-coefficient comparison with various places and the anomalies as described above are evident, as the measure does not include what the income means in terms of what it can purchase.

\section{Insert Table 2-8 Here}

Apparently, the Chinese population is as 'well off' as the American population as far as income disparities are measured, which is not true, as the purchasing powers of incomes in the USA are far greater than those of China (in $19950.445 \mathrm{vs}$ 0.462 and in 20060.440 vs 0.450 ). The Gini-coefficient income disparity measure may be similar, but what does this mean to the various populations concerned? However, the Standard Chartered Bank concludes that income disparity in China is at better levels that those of Hong Kong and Singapore in the early part of the 1980s, and this bank perceives that the disparities are less uneven in China than in many other countries. (Note 12) The World Bank recently showed that a 'drag factor' has also occurred within East Asia in that millions of people have been dragged over the poverty line due to the developing of these economies. However, the income differentiations are relevant to the skill levels possessed by the population. Unskilled are at the bottom, and the skilled at the top, as with any advanced economy. (Note 13)

\section{Major Efforts of China}

Equality with differences has now become the mantra of China. There are rewards for the learning of new skills and their application in industry and administration, provided of course, that the institutions for learning new skills are readily available in both urban and rural situations. Rewards must go to those with talent and desire to become skilled 
and efficient. This current re-evaluation of what is social and economic equality goes into the face of previous government initiatives. This re-evaluation of the productive activities of China brings a new element into the Marxist-Socialist paradigm. Whereas the Soviet Union seemed to discard Marxism in its entirety, China has used a form of Chinese pragmatism to keep both the Socialist state and embrace forms of Capitalism at the same time. This change has caused large problems in that all of this is entirely new to the Chinese population, and deficiencies in administrative functions, and the government's abandonment of some social givens and controls so that the 'New China' can thrive has left those away from the power centres are left somewhat behind. The leadership has acknowledged some of these problems and has opted for policies and actions that stress stability of the PRC over any other factors. Zhu Rong Ji has stated "it is impossible for the government not to regulate the market and not to intervene in prices...without such intervention China will have serious consequences of uneven distribution of wealth". (Note 14)

Recent initiatives have encouraged local populations to raise their living standards and income through self-help and efforts in creating enterprises whose aims is to pull the population out of poverty. This has meant that the local population must learn and earn its rights to economic power with aid and help from government administrators and policies. The hope is that with government money efforts will emanate from the local population that will allow creative used of government funds to become more efficient in the generation of incomes sufficient to pull the population out of poverty. All of this is meant to rely upon community goodwill and honesty to accomplish these aims. However, success is not guaranteed as government finances are being reduced and the subsidisation of poorer regions y the more successful is creating another set of problems. One in particular is that low state salaries are not keeping talent as non-government enterprises are paying higher salaries and the government cannot keep talent within the ranks of the civil service, and this make it difficult to introduce changed policies while keeping the civil servants within the administration and maintaining an honest civil servant and a civil service in general. (Note 15)

Even though this report is almost ten years old, in 1998 the minister of State Planning, Chen Jinhua, in March 6, 1998 gave indications of future government policies concerning living standards, old age social security through pensions, reform and expansion of medical insurance, elimination of illiteracy through nine-year compulsory education, and the establishment of new institutions and research centres as well as vocational training centres. By now these projects ought to be yielding results, further research will establish this.

\subsection{The Future}

What has happened to China in recent years has been that the high economic growth has led to higher incomes that have filtered downwards throughout the economy. This filtering downward effect has been the main reason for poverty alleviation, at the cost of Socialist egalitarianism between rural and urban communities. This is a simple repeat of the histories of Europe and North America, and as a repeat of those histories, the importance of food supply and stability means that the rural community must be supported either directly or indirectly, and in the case of China, this means narrowing the income disparities between city and rural communities through market determinations and gained efficiencies in production.

\section{Conclusions}

Poverty has always been with humanity irrespective of the political system, country, culture, or physical conditions of the population. 'Survival of the fittest' is the natural rule of nature, only man can change that rule and the rules that man has changed have sometime created disasters of great magnitude.

This does not mean that poverty is a given, and that some must be impoverished in order that the majority flourish, it only means that a social conscience may demand that this be allowed or reduced, depending upon the size of the problem. If 10 per cent of the Chinese population are in poverty, then 100 million Chinese are near starvation, and the statistics show that the percentage is larger than this. The real question is how China with such a large impoverished population is able to resolve this problem and still maintain its economic revolution and advancement without overburdening its economy with redistributive taxation, if it can collect such funds in the current state of taxation affairs.

What perhaps is required is a massive education investment as most poverty stricken are illiterate, under-educated, and therefore cannot move to new areas where productive employment is available into jobs that require educated workers that an advancing economy requires. They must take the unskilled work that they can find, if they can find employment at all.

\section{Acknowledgments}

The author gratefully acknowledged the work of to Dr Taejoon Han, Professor of economics at The George Washington University, on the authentic achievements of his paper "China: A share poverty to uneven wealth?, (1995). This paper has influenced the author's thinking in writing this area and some of Dr Taejoon Han ideas and references of the above paper were adopted in this paper. 


\section{References}

Dollar D., and A. Kraay, (2001). Growth is Good for the Poor. Policy Research Working Paper No. 2587, World Bank, Washington, D. C.

Fields, G.. (1988). Changes in Poverty and Inequality in the Developing Countries. Cornell University, Ithaca, NY.

Knight, J., and S. Lina, (2001). "Economic Growth, Economic Reform, and Rising Inequality in China." In Z. Riskin and Li Shi eds., China's Retreat from Inequality: Income Distribution and Economic Transition. New York: M. E. Sharpe.

Riskin, C., Zhao, Renwei, and Li, Shi. (2001). China's Retreat from Equality: Income Distribution and Economic Transition. New York: M. E. Sharpe.

Taejoon Han. (1995). China: A share poverty to uneven wealth?. [Online] Available : http://www.gwu.edu/ econ270/Taejoon.html (12/10/07).

\section{Notes}

Note 1. China Economic Review. Income Inequality Widening. [Online]. (Lexis/Nexis), Nov. 1997 in Taejoon Han (1995)“China: A share poverty to uneven wealth?, (1995).

Note 2. US-China Business Council. Shifting Boundaries; China's Rural Population, The China Business Review, [Online]. (Lexis/Nexis), Information Access Company, Sept. 19, 1997 in Taejoon Han (1995)“China: A share poverty to uneven wealth?, (1995).

Note 3. World Bank. China 2020: Sharing Rising Incomes: Disparities in China. The IBRD, 1997 (p.16).in Taejoon Han (1995)“China: A share poverty to uneven wealth?, (1995).

Note 5. Jane Macartney. China: China Economic Chief Praises Keynes, Price Control. Reuter Textline [Online]. (Lexis/Nexis), May 17, 1995. in Taejoon Han (1995)“China: A share poverty to uneven wealth?, (1995).

Note 6. Lu Jingxian. China: State Works to Narrow Income Disparities. Reuter Textline, China Daily, [Online]. December 10, 1996 in Taejoon Han (1995)“China: A share poverty to uneven wealth?, (1995).

Note 7. Business Times (Singapore). A Chinese High Savings Puzzle. Times Business Publications, [Online]. (Lexis/Nexis), May 30, 1996.in Taejoon Han (1995)“China: A share poverty to uneven wealth?, (1995).

Note 8. Jung Dong Park. China in 21st Century, Korea Economic Daily Publishing Co, July 1997. (pp.87-88) in Taejoon Han (1995)“China: A share poverty to uneven wealth?, (1995). In Taejoon Han (1995)“China: A share poverty to uneven wealth?, (1995).

Note 9. Liqun Jia and Clem Tisdell. Resource Redistribution and Regional Income Inequality in China. Asian Economies, The Institute of Asian Economies, June 1996.in Taejoon Han (1995)“China: A share poverty to uneven wealth?, (1995).

Note 11. Hak Choi. Inequality of Income Growth in China. Asian Economies, The Institute of Asian Economies, Dec. 1996. in Taejoon Han (1995)“China: A share poverty to uneven wealth?, (1995).

Note 12. South China Morning Post. Mainland Income Gap 'Exaggerated'. South China Morning Post Ltd, [Online]. (Lexis/Nexis), January 22, 1998. in Taejoon Han (1995)“China: A share poverty to uneven wealth?, (1995).

Note 13. World Bank. Poverty and Inequality-The Other Face of the Asia Miracle. The IBRD, [Online], Aug. 26, 1997, Available:http://www.rocks.worldbank.org/html/extdr/extme/1450.htm. 14. Jane Macartney, May 17, 1995. in Taejoon Han (1995)“China: A share poverty to uneven wealth?, (1995).

Note 15. Shen Shuisheng and Yao Yuqun. On the Problems of Distribution of Social Income in China. Chinese Economic Studies, vol.29, no.6, Nov.-Dec.1996, (pp.6-17).in Taejoon Han (1995)“China: A share poverty to uneven wealth?, (1995). 
Table 2-1. Percentage of Rural Households Grouped by per Capita Annual Income

\begin{tabular}{lrrrrrr} 
Rural Households & $\mathbf{1 9 9 0}$ & $\mathbf{1 9 9 5}$ & $\mathbf{2 0 0 0}$ & $\mathbf{2 0 0 4}$ & $\mathbf{2 0 0 5}$ \\
Less Than 500 Yuan & 35.05 & 5.12 & 2.64 & 1.58 & 1.68 \\
$500-1500$ Yuan & 59.48 & 51.49 & 29.45 & 18.58 & 15.19 \\
1500-2500 Yuan & 3.48 & 27.6 & 32.47 & 27.95 & 25.05 \\
2500-3500 Yuan & 1.99 & 9.38 & 17.40 & 20.61 & 20.97 \\
3500 Yuan and above & 0 & 6.41 & 18.04 & 31.28 & 37.11 \\
\hline
\end{tabular}

Source: China Annual Statistics Book, 2006

Table 2-2. Per Capita Annual Income of Urban and Rural Household

$\begin{array}{lllllllllllll} & 1985 & 1986 & 1987 & 1988 & 1989 & 1990 & 1991 & 1992 & 1993 & 1994 & 1995 & 1996 \\ \text { Rural } & 397.6 & 432.8 & 462.6 & 544.9 & 601.5 & 686.3 & 708.6 & 784.0 & 921.6 & 1221.0 & 1557.7 & 1926.1 \\ \text { Urban } & 685.3 & 827.9 & 916.0 & 1119.4 & 1260.7 & 1387.3 & 1544.3 & 1826.1 & 2336.5 & 3179.2 & 3892.9 & 4377.2\end{array}$

$\begin{array}{llllllllll} & 1997 & 1998 & 1999 & 2000 & 2001 & 2002 & 2003 & 2004 & 2005 \\ \text { Rural } & 2090.1 & 2162.0 & 2210.3 & 2253.4 & 2366.4 & 2475.6 & 2622.2 & 2936.4 & 3254.9 \\ \text { Urban } & 5160.3 & 5425.1 & 5824.0 & 6280.0 & 6859.6 & 7702.8 & 8472.2 & 9421.6 & 10493\end{array}$

Source: China Annual Statistics Book, 2006

Table 2-3. A Comparison on per capita annual income of urban vs. rural residents (2005 in Yuan)

\begin{tabular}{|c|c|c|c|c|c|}
\hline & Rural & Urban & & & Urban \\
\hline Region & Residents & Residents & Region & Rural Residents & Residents \\
\hline Shanghai & 8247.77 & 20602.90 & Inner Mongolia & 2988.87 & 9565.14 \\
\hline Beijing & 7346.26 & 19533.33 & Shanxi & 2890.66 & 9538.56 \\
\hline Zhejiang & 6659.95 & 17877.36 & Hubei & 3099.20 & 9395.10 \\
\hline Guangdong & 4690.49 & 16249.89 & Anhui & 2640.96 & 9184.55 \\
\hline Tianjin & 5579.87 & 13563.32 & Henan & 2870.58 & 9145.98 \\
\hline Fujian & 4450.36 & 13407.60 & Jilin & 3263.99 & 9122.99 \\
\hline Jiangsu & 5276.29 & 13329.95 & Jiangxi & 3128.89 & 9042.45 \\
\hline Shandong & 3930.55 & 11607.82 & Sichuan & 2802.78 & 9003.59 \\
\hline Chongqing & 2809.32 & 11079.15 & Shaanxi & 2052.63 & 8902.26 \\
\hline Tibet & 2077.90 & 10659.31 & Qinghai & 2151.46 & 8766.68 \\
\hline Hunan & 3117.74 & 10106.07 & Ningxia & 2508.89 & 8744.86 \\
\hline Guangxi & 2494.67 & 10022.40 & Gansu & 1979.88 & 8738.11 \\
\hline Yunnan & 2041.79 & 9994.65 & Heilongjiang & 3221.27 & 8722.47 \\
\hline Liaoning & 3690.21 & 9837.20 & Xinjiang & 2482.15 & 8693.67 \\
\hline \multirow[t]{2}{*}{ Hebei } & 3481.64 & 9616.80 & Hainan & 3004.03 & 8670.15 \\
\hline & & & Guizhou & 1876.96 & 8385.08 \\
\hline
\end{tabular}

Source: China Annual Statistics Book, 2006 
Table 2-4. Per Capita Annual Income by region (1994 and 2005).

\begin{tabular}{|c|c|c|c|c|c|c|c|c|}
\hline Eastern & \begin{tabular}{|l} 
Per \\
Capita \\
Annual \\
Income \\
1994
\end{tabular} & \begin{tabular}{|l} 
Per \\
Capita \\
Annual \\
Income \\
2005
\end{tabular} & Central & $\begin{array}{l}\text { Per } \\
\text { Capita } \\
\text { Annual } \\
\text { Income } \\
1994\end{array}$ & $\begin{array}{l}\text { Per Capita } \\
\text { Annual } \\
\text { Income } \\
2005\end{array}$ & Western & $\begin{array}{l}\text { Per Capita } \\
\text { Annual } \\
\text { Income } \\
1994\end{array}$ & $\begin{array}{l}\text { Per Capita } \\
\text { Annual } \\
\text { Income } \\
2005\end{array}$ \\
\hline Hebei & 1442.48 & 12588.73 & & & & Shanxi & 853.27 & 11804.57 \\
\hline Tianjin & 3383.85 & 18218.42 & & & & Gansu & 1041.97 & 10066.70 \\
\hline Beijing & 4417.85 & 24999.21 & In Mongol & 1112.49 & 12125.66 & Ningxia & 1020.06 & 10602.53 \\
\hline Shandong & 1682.51 & 14675.34 & Shanaxi & 1186.92 & 10324.55 & Sichuan & 985.39 & 11188.74 \\
\hline Jiangsu & 2613.54 & 17594.86 & Henan & 1019.15 & 11538.55 & Yunnan & 942.46 & 11307.69 \\
\hline Shanghai & 7555.89 & 26892.80 & Anhui & 1047.83 & 11111.64 & Guizhou & 609.80 & 10028.09 \\
\hline Zhejiang & 2443.99 & 22953.72 & Hubei & 1341.40 & 11885.14 & Qinghai & 1055.46 & 10209.31 \\
\hline Fujian & 1674.75 & 16771.67 & Hunan & 977.06 & 12641.71 & Xinjiang & 1456.63 & 10472.30 \\
\hline Guangdong & 2450.21 & 19460.43 & Jiangxi & 1106.78 & 11748.55 & Tibet & 930.86 & 11509.08 \\
\hline Guangxi & 842.88 & 11781.37 & & & & & & \\
\hline Hainan & 1753.22 & 11127.97 & & & & & & \\
\hline \multicolumn{3}{|c|}{$\begin{array}{l}\text { Per Capita } \\
\text { Annual Income } \\
1994\end{array}$} & \multicolumn{2}{|c|}{$\begin{array}{l}\text { Per Capita } \\
\text { Annual } \\
\text { Income 2005 }\end{array}$} & & & & \\
\hline Liaoning & \multicolumn{2}{|c|}{2099.40} & \multicolumn{2}{|l|}{12797.76} & & & & \\
\hline Heilongjiang & \multicolumn{2}{|c|}{1541.01} & \multicolumn{2}{|l|}{11493.78} & & & & \\
\hline Jilin & \multicolumn{2}{|c|}{1456.39} & \multicolumn{2}{|l|}{11954.61} & & & & \\
\hline
\end{tabular}

Source: China Statistical Yearbook, 2006.

Table 2-5. Main Social and Economic Indicators by Region (2005)

Main Social and Economic Indicators by Region (2005)

\begin{tabular}{lllll} 
& Eastern & Central & Western & North-eastern \\
*1 Number of Employed Persons & 24810.10 & 19065.48 & 19448.01 & 4703.85 \\
GDP (100 mil. Yuan ) & 109924.64 & 37230.30 & 33493.31 & 17140.78 \\
Number of Industrial Enterprises & 865742.00 & 247697.00 & 170551.00 & 91273.00 \\
& & & & 17645.04 \\
Total Number of Investment in Fixed & 45626.30 & 16145.55 & 17645.04 & 4016.5 \\
$\begin{array}{l}\text { Assets } \\
\text { *3 Gross Agricultural Output Value }\end{array}$ & 15428.1 & 10434.5 & 9571.7 & 2945.9 \\
*4 Number of Telephone Sets & 12774.5 & 5989.9 & 5369.7 & 2044.64 \\
*5 Annual Electricity Consumption & 12638.40 & 4736.55 & 5337.85 & 182.00 \\
*6 Number of Higher Education Institute & 714.00 & 468.00 & 428.00 & 32006.00 \\
\hline Number of Health Institutions & 98780.00 & 68317.00 & 99894.00 \\
\hline
\end{tabular}

Source: China Annual Statistics Book, 2006. 
Table 2-6. Main Social and Economic Indicators by Region - Modified (2005).

Main Social and Economic Indicators by Region- Modified (2005)

Total Population ( in 10,000)

*1 Percentage of Employed Persons

Per Capita GDP

Number of Telephone Sets

Per Capita Annual Electricity Consumption

*3, 4 Number of Higher Education Institute

*3 Number of Health Institutions

\begin{tabular}{llll} 
Eastern & Central & Western & North-eastern \\
46388.00 & 35202.00 & 35976.00 & 10757.00 \\
53.5 & 54.2 & 54.1 & 43.7 \\
23767.90 & 10607.90 & 9338.20 & 15982.40 \\
0.2754 & 0.1702 & 0.1493 & 0.2739 \\
2724.50 & 1345.53 & 1483.73 & 1900.75 \\
0.01539 & 0.01329 & 0.01190 & 0.01692 \\
2.1294 & 1.9407 & 2.7767 & 2.9754 \\
\hline
\end{tabular}

Source: China Annual Statistics Book, 2006.

Table 2-7. Comparison of Gini index.

\begin{tabular}{|c|c|c|c|c|c|c|c|c|c|c|c|c|c|c|c|}
\hline & 1981 & 1982 & 1983 & 1984 & 1985 & 1986 & 1987 & 1988 & 1989 & 1990 & 1991 & 1992 & 1993 & 1994 & 1995 \\
\hline Rural & 0.239 & 0.232 & 0.246 & 0.258 & 0.264 & 0.288 & 0.292 & 0.301 & 0.300 & 0.310 & 0.307 & 0.314 & 0.320 & 0.330 & 0.340 \\
\hline
\end{tabular}

\begin{tabular}{|l|l|l|l|l|l|l|l|l|l|}
\hline & 1997 & 1998 & 1999 & 2000 & 2001 & 2002 & 2003 & 2004 & 2005 \\
\hline Rural & 0.371 & 0.378 & 0.389 & 0.409 & 0.403 & 0.432 & 0.439 & 0.439 & 0.440 \\
\hline
\end{tabular}

Source: Zhao Renwei \& Li Shi (1997), "Increasing Income Inequality and Its Cause in China," Journal of Economic Research, No.9 and Dr Taejoon Han (1995) paper "China: A share poverty to uneven wealth? (1995).

Table 2-8. Comparison of Gini index beween selected economies

\begin{tabular}{|l|l|l|l|l|l|l|l|}
\hline & China & US & Korea & Thailand & Indonesia & Mexico & Chile \\
\hline Survey Year & 1995 & 1994 & 1994 & 1992 & 1993 & 1992 & 1994 \\
\hline Gini-coefficient & 0.445 & 0.462 & 0.285 & 0.462 & 0.320 & 0.503 & 0.565 \\
\hline Survey Year & 2006 & 2006 & 2006 & 2006 & 2006 & 2006 & 2006 \\
\hline Gini-coefficient & 0.440 & 0.450 & 0.358 & 0.511 & 0.343 & 0.546 & 0.571 \\
\hline
\end{tabular}

Source: Zhao Renwei \& Li Shi (1997), "Increasing Income Inequality and Its Cause in China," Journal of Economic Research, No.9. Source: Zhao Renwei \& Li Shi (1997), "Increasing Income Inequality and Its Cause in China," Journal of Economic Research, No.9 and Dr Taejoon Han (1995) paper “China: A share poverty to uneven wealth? (1995).

$$
\text { US Census Bureau. }
$$

World Bank, Selected World Development Indicators 2006. 


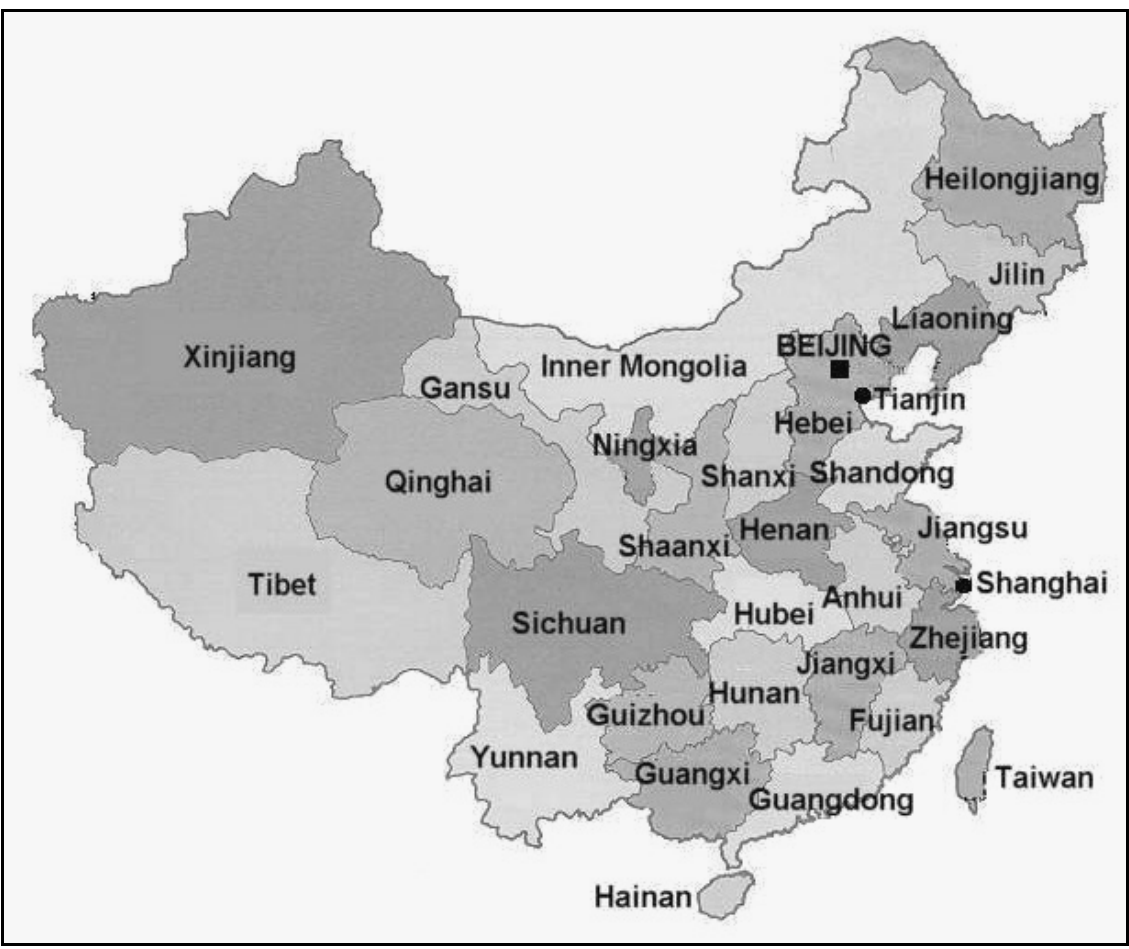

Figure 1-1. Map of China with 22 province level of administrative division

\section{Percentage of Rural Households Grouped by Per Capita Annual Net Income}

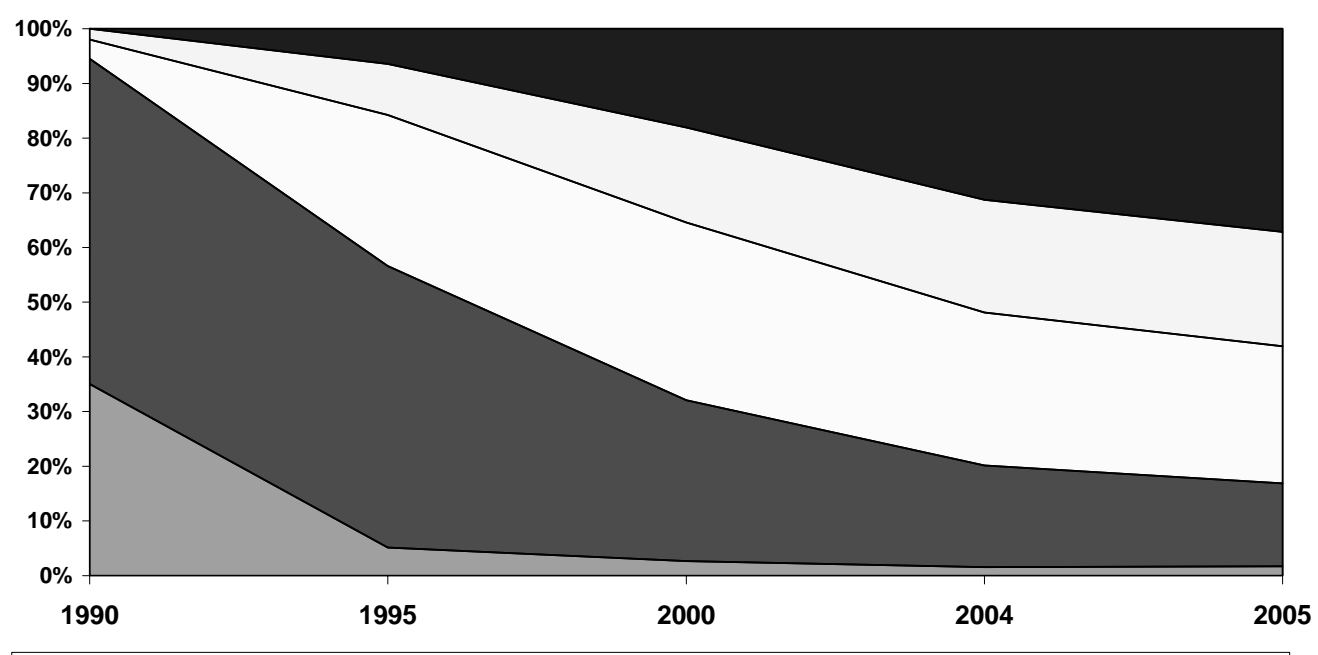

$\square$ Less Than 500 Yuan $\square$ 500-1500 Yuan $\square$ 1500-2500 Yuan $\square$ 2500-3500 Yuan $\square 3500$ Yuan and above

Source: China Annual Statistics Book, 2006

Figure 2-1. Percentage of Rural Households Grouped by per Capita Annual Income 


\section{Per Capita Annual Income of Urban and Rural Household}

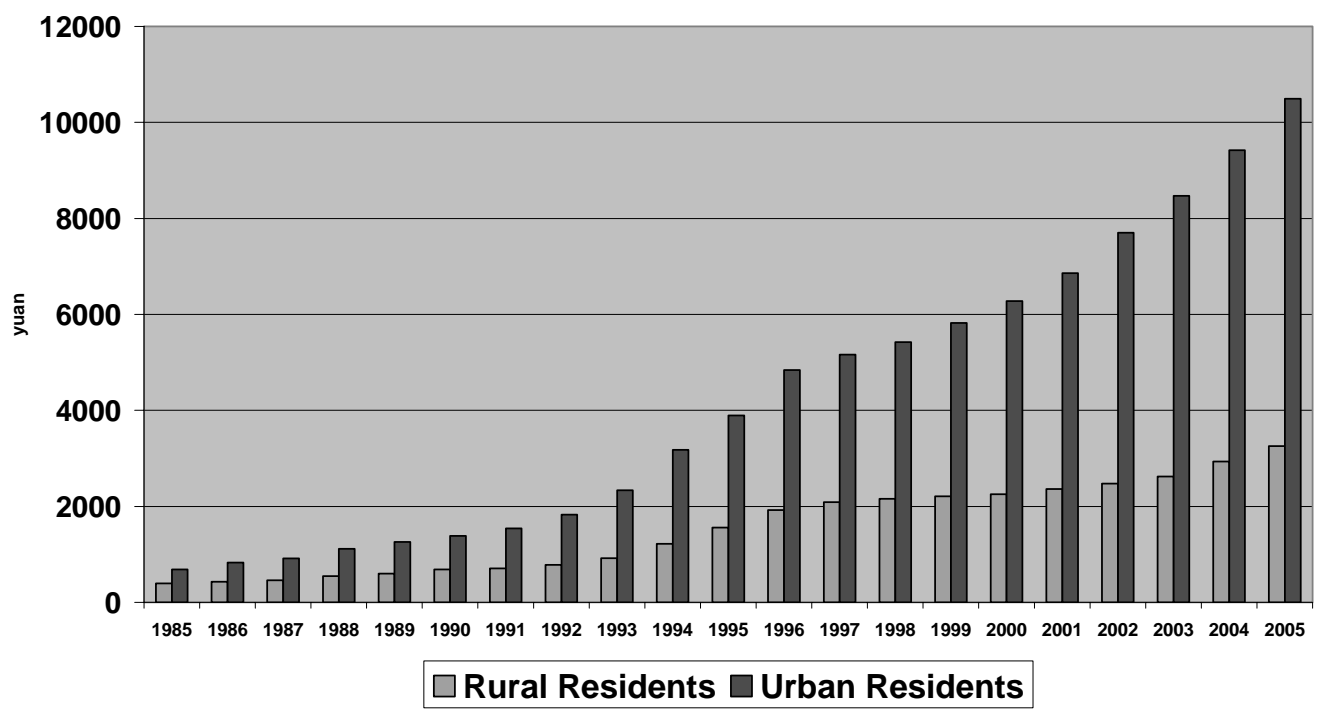

Figure 2-2. Wage Income of Rural Residents vs. Urban Residents

Source: China Annual Statistics Book, 2006.

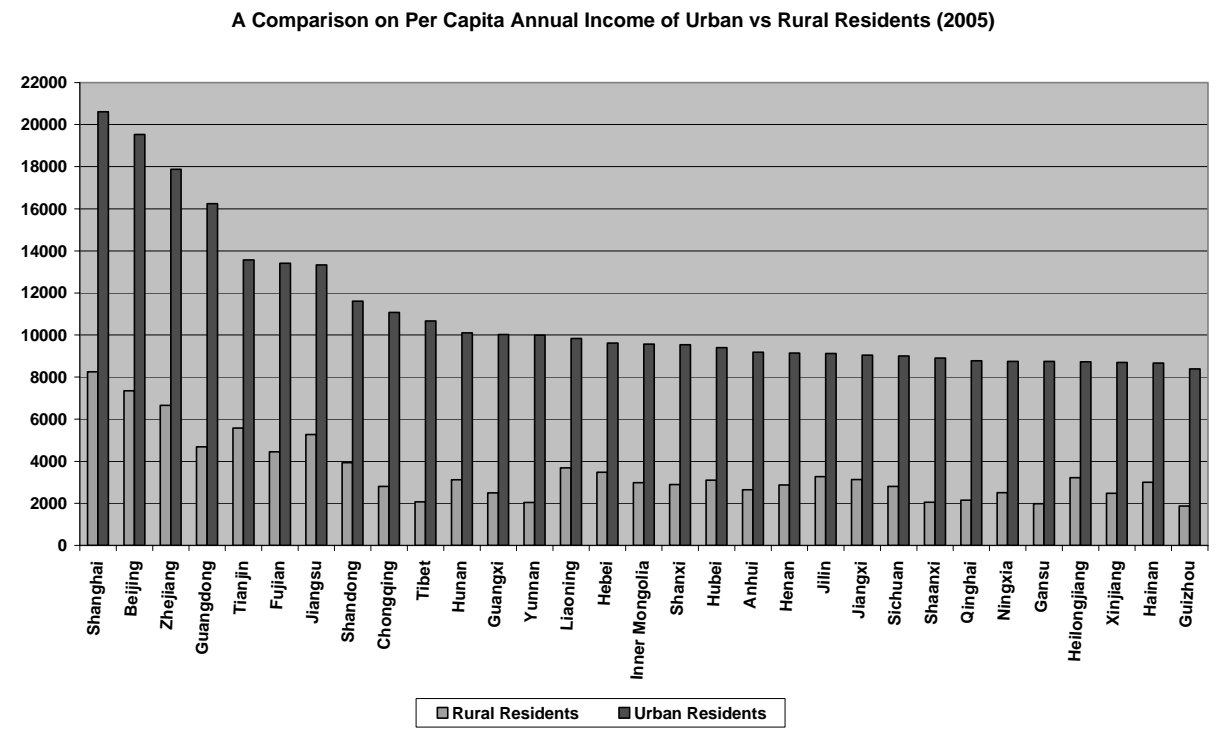

Figure 2-3. A Comparison on per capita annual income of urban vs. rural residents (2005 in Yuan) Source: China Annual Statistics Book, 2006 